\title{
The Question of Esoteric Writing in Machiavelli's Works
}

RASOUL NAMAZI

Leo Strauss Center, University of Chicago

The question addressed by this article is whether esotericism or secret teachings exist in Machiavelli's writings. This question has been a major point of contention between the commentators of Machiavelli, with many denying the existence of esoteric teaching in the Machiavellian corpus. This article will explore the controversy by studying Machiavelli's own works, and on this basis it will be contended that there are many references and elements present in Machiavelli's works that justify an esoteric interpretation. Consequently, it is reasonable to assume that Machiavelli has esoteric intentions that are different from the surface meaning of his texts. It is therefore necessary for commentators to go beyond the surface of his writings to uncover his deeper teachings.

Cet article se penche sur la question de la présence d'éléments ésotériques ou d'enseignements secrets dans l'œuvre de Machiavel. Le sujet est un point de désaccord important parmi les commentateurs de l'ouvre de Machiavel, puisque plusieurs nient l'existence d'un tel enseignement. L'article explore cette controverse en examinant l'ouvre de Machiavel, pour ensuite montrer qu'il s'y trouve plusieurs références et éléments justifiant une interprétation ésotérique. En conséquence, il est vraisemblable que Machiavel ait eu des intentions ésotériques différentes du propos apparent de ses écrits. Il s'avère donc nécessaire que les commentateurs aillent plus loin que la surface de son cuvre afin de découvrir ses enseignements cachés.

ny commentator who begins the study of Niccolò Machiavelli will be
surprised by the number of works written on his thought. In his 1953 article, Isaiah Berlin noted that the bibliography of secondary literature on Machiavelli contains more than three thousand items. Since then, presumably, several thousand titles have been added. ${ }^{1}$ The diversity of these writings is also remarkable; there remains practically no interpretation that has not been defended by one commentator or another. However, among all the competing interpretations of Machiavelli, it would be difficult to find any as controversial as those based on an esoteric reading of his works. Esotericism, broadly defined, means "every form of secretiveness in the communication

1. Isaiah Berlin, “The Originality of Machiavelli”, in Against the Current: Essays in the History of Ideas (New York: Viking, 1980), 25n2; Silvia R. Fiore, Niccolò Machiavelli: An Annotated Bibliography of Modern Criticism and Scholarship (Westport: Greenwood Press, 1990). 
of thought." ${ }^{2}$ Here, it is the idea that Machiavelli's works contain more than their literal meanings and that this esoteric meaning is intended by Machiavelli himself. Esoteric commentaries on Machiavelli have their origins in the work of Leo Strauss. ${ }^{3}$ His reading of Machiavelli was based on the esoteric principle that the surface meaning of Machiavelli's texts does not always indicate his real intention. According to Strauss, for reasons mostly related to religious and political persecution, Machiavelli practised esoteric techniques in his works to conceal his profound and subversive insights from the common reader. In other words, Machiavelli is an esoteric writer who conveys his real teaching only to a select group of readers who are familiar with the secretive or esoteric mode of communication. For Strauss, Machiavelli in his writings "does not go to the end of the road; the last part of the road must be travelled by the reader who understands what is omitted by the writer." ${ }^{34} \mathrm{He}$ argued that one must go beyond the surface and literal meaning of Machiavelli's writings to uncover his esoteric teaching. Strauss believed that contrary to what one might come to think from reading many traditional-looking passages, Machiavelli is a radically innovative and irreligious thinker who questions many principles of ancient and Christian thought and intends to replace them with a new and revolutionary doctrine.

The reactions to Strauss's interpretation have been diverse: many completely ignored it, some made very short remarks about it, and some scholars agreed with Strauss and followed in his footsteps. One curious aspect of the reactions is that only a few scholars who disagreed with Strauss's interpretation have tried to discuss his findings in detail and begin a serious dialogue with

2. Arthur M. Melzer, Philosophy between the Lines: The Lost History of Esoteric Writing (Chicago: University of Chicago Press, 2014), 368n3. A similar definition is also found in Johann Heinrich Samuel Formey's article "Exotérique et Esotérique," in Encyclopédie of Diderot and D’Alembert: “The ancient philosophers had a double doctrine; one external, public or exoteric; the other internal, secret or esoteric." Quoted in Christopher Kelly, Rousseau as Author: Consecrating One's Life to the Truth (Chicago: University of Chicago Press, 2003), 147.

3. Leo Strauss, "Machiavelli's Intention: The Prince," The American Political Science Review 51.1 (1957): 13-40; Leo Strauss, Thoughts on Machiavelli (Glencoe, IL: Free Press, 1958); Leo Strauss, "Machiavelli and Classical Literature," Review of National Literatures 1.1 (Spring 1970): 7-25; Leo Strauss, "Niccolò Machiavelli," in History of Political Philosophy, ed. Joseph Cropsey and Leo Strauss, 2nd ed. (Chicago: University of Chicago Press, 1972), 271-92.

4. Strauss, Thoughts on Machiavelli, 34-35. 
him. ${ }^{5}$ The principal source of this lack of fruitful discussion has been the question of esotericism. Long ago, J. G. A. Pocock objected to Strauss's reading of Machiavelli. He believed Strauss's esoteric method was perfectly legitimate in the case of Muslim philosophers: "we know esoteric writing can be found in the falasifa because the falasifa tell us it is there." In Machiavelli's case, however, esoteric interpretation is problematic because, according to Pocock, even Strauss confesses that Machiavelli "conceals the very fact that he is communicating

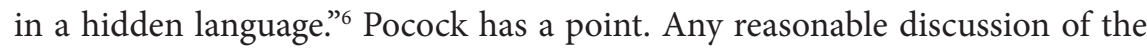

5. J. G. A. Pocock conspicuously omitted Strauss in his monumental work, The Machiavellian Moment: Florentine Political Thought and the Atlantic Republican Tradition (Princeton: Princeton University Press, 1975). See below for his later reaction. For very short remarks from prominent commentators, see the following: Quentin Skinner, Machiavelli: A Very Short Introduction (Oxford: Oxford University Press, 2001), 99; Quentin Skinner, The Foundations of Modern Political Thought_Volume One: The Renaissance (Cambridge: Cambridge University Press, 1978), 137; Maurizio Viroli, Machiavelli (Oxford: Oxford University Press, 1998), 175n8, 208n150; Maurizio Viroli, Niccolo's Smile: A Biography of Machiavelli, trans. Antony Shugaar (New York: Farrar Straus Giroux, 2000), 156. For more detailed discussions of Strauss's reading, see Dante Germino, "Second Thoughts on Leo Strauss's Machiavelli," Journal of Politics 28 (1966): 794-817; Dante Germino, "Blasphemy and Leo Strauss's Machiavelli," in Leo Strauss: Political Philosopher and Jewish Thinker, ed. Kenneth L. Deutsch and Walter Nicgorski (Lanham: Rowman \& Littlefield, 1994); Claude Lefort, Le Travail de l'Euvre Machiavel (Paris: Gallimard, 1972); Heinrich Meier, Political Philosophy and the Challenge of Revealed Religion, trans. Robert Berman (Chicago and London: University of Chicago Press, 2017). The following works fit within the broad range of the most influential esoteric interpretations of Machiavelli: Leo Paul de Alvarez, The Machiavellian Enterprise: A Commentary on The Prince (DeKalb: Northern Illionois University Press, 1999); Patrick J. Coby, Machiavelli's Romans (Lanham: Lexington Books, 1999); Christopher Lynch, "Machiavelli on Reading the Bible Judiciously," Hebraic Political Studies 1.2 (2006): 162-85; Pierre Manent, Histoire Intellectuelle Du Liberalisme (Paris: Calmann-Levy, 1987); Pierre Manent, Naissances de La Politique Moderne (Paris: Gallimard, 2007); Harvey C. Mansfield, Machiavelli's Virtue (Chicago: University of Chicago Press, 1998); Harvey C. Mansfield, Machiavelli's New Modes and Orders: A Study of the Discourses on Livy (Chicago: University of Chicago Press, 2001); Paul Rahe, Against Throne and Altar: Machiavelli and Political Theory under the English Republic (Cambridge: Cambridge University Press, 2008); Harvey C. Mansfield, "The Cuckold in Machiavelli's Mandragola," in The Comedy and Tragedy of Machiavelli: Essays on the Literary Works, ed. Vickie B. Sullivan (New Haven: Yale University Press, 2000), 1-30; Nathan Tarcov, "Machiavelli and the Foundations of Modernity: A Reading of Chapter 3 of The Prince," in Educating the Prince: Essays in Honour of Harvey Mansfield, ed. Mark Blitz and William Kristol (Lanham: Rowman \& Littlefield, 2000), 30-44; Nathan Tarcov, "Belief and Opinion in Machiavelli's Prince," The Review of Politics 75 (2013): 573-86; Nathan Tarcov, "Machiavelli's Critique of Religion," Social Research: An International Quarterly 81.1 (2014): 193-216.

6. J. G. A. Pocock, "Prophet and Inquisitor: Or, a Church Built upon Bayonets Cannot Stand: A Comment on Mansfield's 'Strauss's Machiavelli', Political Theory 3.4 (1975): 388. Pocock's article is part 
esoteric commentaries depends on the previous settlement of the question of the presence of esotericism in Machiavelli's work. If the question of Machiavelli's esotericism remains controversial, any esoteric reading of his works is also bound to be controversial. Later in the same piece Pocock concedes that "there are some hidden and indirectly conveyed-messages in Machiavelli." ${ }^{\prime}$ However, this concession appears only in this article, and nowhere else in his writings on Machiavelli does Pocock mention or discuss any "hidden and indirectly conveyed-messages." Other non-Straussian commentators have also refrained from discussing any hidden message in Machiavelli's writings; it seems that the radical denial of esotericism is the non-Straussian camp's working principle. ${ }^{8}$ Furthermore, Pocock never explained why he believes in the existence of some hidden messages in Machiavelli's works. This seems to be the reason why his concession was never followed by other non-Straussian commentators, who still regularly ignore the esoteric interpretations of Machiavelli. Therefore, the question of esotericism still needs to be addressed before evaluating the esoteric commentaries.

However, there is no independent study of Machiavelli's esotericism. Esoteric commentators often presuppose the existence of esotericism in Machiavelli's writings, and some evidence supporting the existence of esotericism in Machiavelli's works is dispersed in their commentaries. Moreover, in their writings, the question of Machiavelli's esotericism is often associated with specific interpretations of his texts. For instance, consider the only quotation from the Bible found in Discourses (1.26.61). ${ }^{9}$ Machiavelli uses

of an exchange consisting of three pieces published in the same issue: an article by Harvey C. Mansfield (“Strauss's Machiavelli," 372-84), Pocock's comment, and Mansfield's reply ("Reply to Pocock," 402-05). See also Frederick Vaughan, “On 'An Exchange on Strauss's Machiavelli', Political Theory 4.3 (1976): 371-72; Harvey C. Mansfield, "Strauss on The Prince," The Review of Politics 75 (2013): 641-65.

7. Pocock, "Prophet and Inquisitor," 395.

8. For a few remarkable non-Straussian scholars who discuss some esoteric aspects of Machiavelli's writings, see Mary G. Dietz, "Trapping the Prince: Machiavelli and the Politics of Deception," American Political Science Review 80 (1986): 777-99; Victoria Kahn, “Reading Machiavelli: Innocent Gentillet's Discourse on Method," Political Theory 22.4 (1994): 539-60; John P. McCormick, "Faulty Foundings and Failed Reformers in Machiavelli's Florentine Histories," American Political Science Review 111.1 (February 2017): 204-16.

9. The following abbreviations are used for Machiavelli's works: AW = Art of War; C $=$ Clizia; $\mathrm{D}=$ Discourses on the First Decade of Titus Livy; FH = Florentine Histories; $\mathrm{L}=$ Personal Correspondence; $\mathrm{M}=$ Mandragola $; \mathrm{O}=$ Tutte le Opere $\mathrm{P}=$ The Prince. The following translations and editions are used: 
a famous quotation from the New Testament (also a part of the Magnificat that is frequently sung in church services) for describing the actions of David, while the biblical passage is in fact about God. Machiavelli then describes the actions similar to David's as being "very cruel" and the enemy to every way of life. The esoteric commentator will conclude that this is Machiavelli's esoteric way of saying that God "like Philip of Macedon" (also mentioned in the chapter) is a cruel and inhuman tyrant. ${ }^{10}$ There are many such examples of suspicious passages, and their esoteric interpretation is often proposed as a sign of esoteric intentions in Machiavelli's works. However, there are also common objections to such esoteric interpretations: one can explain away these problematic passages by some alternative interpretation, pointing to the possible carelessness of the author or other customary devices. A case in point is Leslie J. Walker, who believed that "Machiavelli would often have heard the Magnificat sung, but appears to have but a hazy notion of what it is all about." In other words, Machiavelli's misquotation could simply be an example of unintentional carelessness. ${ }^{11}$

One can provide counterarguments to such objections. For instance, one might question the possibility that a thinker of Machiavelli's calibre who could ably comment on Savonarola's biblical sermons (L 8-10) and write

AW = Niccolò Machiavelli, Art of War, trans. Christopher Lynch (Chicago: University of Chicago Press, 2003). C = Niccolò Machiavelli, The Comedies of Machiavelli: The Woman from Andros, The Mandrake, Clizia, trans. David Sices and James B. Atkinson (Indianapolis: Hackett Publishing, 1985). D = Niccolò Machiavelli, Discourses on Livy, trans. Harvey C. Mansfield and Nathan Tarcov (Chicago: University of Chicago Press, 1996). FH = Niccolò Machiavelli, Florentine Histories, trans. Harvey C. Mansfield and Laura F. Banfield (Princeton: Princeton University Press, 1988). L = Niccolò Machiavelli, Machiavelli and His Friends: Their Personal Correspondence, trans. James B. Atkinson and David Sices (DeKalb: Northern Illinois University Press, 1996). M = Machiavelli, The Comedies of Machiavelli: The Woman from Andros, The Mandrake, Clizia. O = Niccolò Machiavelli, Tutte Le Opere, ed. Mario Martelli (Florence: Sansoni, 1971). P = Niccolò Machiavelli, The Prince, trans. Harvey C. Mansfield, 2nd ed. (Chicago: University of Chicago Press, 1998). For numbers after abbreviations: AW = book and sentence numbers; $\mathrm{C}=$ page numbers; $\mathrm{D}=$ book, chapter, and page numbers; $\mathrm{FH}=$ book, chapter, and page numbers; $\mathrm{L}=$ page numbers; $\mathrm{M}=$ page numbers; $\mathrm{O}=$ page numbers; $\mathrm{P}=$ chapter and page numbers.

10. Strauss, Thoughts on Machiavelli, 49; Mansfield, Machiavelli's New Modes and Orders, 99.

11. Leslie J. Walker, The Discourses of Niccolò Machiavelli, ed. Cecil H. Clough (London: Routledge, 1975), 53n1; Mario Martelli, Machiavelli E Gli Storici Antichi (Rome: Salerno, 1998), 27; Sydney Anglo, Machiavelli-The First Century: Studies in Enthusiasm, Hostility, and Irrelevance (Oxford: Oxford University Press, 2005), 92; Pocock, "Prophet and Inquisitor," 396-97; Germino, "Second Thoughts on Leo Strauss's Machiavelli”; Germino, "Blasphemy and Leo Strauss's Machiavelli." 
a theologically complex text such as Exhortation to Penitence (O 932-34) would not know what the Magnificat is about. ${ }^{12}$ Nevertheless, one can and should separate the question of Machiavelli's esotericism from any specific or controversial interpretation. A commentator should be able to subscribe to the esoteric method of interpretation without agreeing with any specific reading of Machiavelli. In other words, to make the question of esotericism dependent on some specific interpretation of passages (or "little things"13) is avoidable. The question of esotericism is independent of any specific interpretation and can be supported by self-sufficient proofs. Furthermore, it does not help the historical question of esotericism that some of Machiavelli's esoteric commentators actually practise esoteric writing themselves and pay much attention to numerology. ${ }^{14}$ These practices make the discussion of esotericism difficult and controversial. Moreover, while its relevance has often been ignored, there is much evidence from Machiavelli's correspondence, anecdotal accounts, literary writings, and minor works proving the existence of esotericism in his thought.

For these reasons, this study will present and discuss the references and elements found in Machiavelli's own writings that justify an esoteric interpretation of his work. This will be done while avoiding controversial interpretations as much as possible. My article begins with a summary of those aspects of Machiavelli's person and thought that can produce a general suspicious attitude in commentators and persuade them to acknowledge the possibility of esotericism in the Machiavellian corpus. I will then turn to those writings of Machiavelli that invite esoteric interpretation because of their literary forms. In the following section, Machiavelli's references to his own esotericism are discussed. Finally, I will study Machiavelli's own esoteric reading of other writers and the passages in his writings that can be interpreted as allusions to esotericism. ${ }^{15}$

12. Roberto Ridolfi, The Life of Niccolò Machiavelli, trans. Cecil Grayson (Chicago: University of Chicago Press, 1963), 253, 328n2; Sebastian de Grazia, Machiavelli in Hell (Princeton: Princeton University Press, 1989), 59.

13. Mansfield, “Strauss's Machiavelli,” 379.

14. Mansfield, "Strauss on The Prince," 642; Mansfield, Machiavelli's New Modes and Orders, 13, 33n1; Melzer, xii.

15. The recent and excellent study by Melzer (Philosophy between the Lines; see note 2) is entirely devoted to the question of esotericism. The considerable number of quotations presented in his work and his arguments prove that esotericism has been a well-known and common practice for many writers 


\section{Machiavelli's esoteric character}

Why would anyone suspect the existence of esotericism in Machiavelli's writings? This is partly due to the specific character of Machiavelli's person and thought: he was not an ordinary philosopher or political theorist, but a practising diplomat and military advisor. These roles have always been intimately connected to secrecy and deception, and in fact, many references in the Machiavellian corpus that can be used for studying esotericism in his writings are related to diplomacy or warfare. Moreover, in all his writings Machiavelli shows a strong inclination toward the question of conspiracy. Esotericism is also a kind of conspiracy: it is secretiveness in the communication of thought, and Machiavelli often mentions the importance of secret communications in conspiracies. In other words, many of Machiavelli's statements that can be interpreted as allusions to esotericism are in fact related to secretiveness about matters different from the writing of books. Here it is necessary to study some of these references in greater detail to gain a better understanding of the passages involved.

Most of Machiavelli's career during the Florentine Republic was dedicated to diplomatic missions. His private and public writings on diplomatic questions are an important source of references to the secret art of writing and esotericism. For instance, in his note to a future diplomat, Raffaello Girolami, he advises that a diplomat should strive not to appear to believe one thing and say another. $\mathrm{He}$ concedes that sometimes a diplomat needs to conceal his beliefs, but he insists that he should do it in such a way that it does not become known. Moreover, he advises Girolami to present his own ideas in his reports as those of a third party. ${ }^{16}$ As we shall see later, the practice of attributing one's own thoughts to others is considered by Machiavelli to be a recurring characteristic of many writers. Also, in two letters to Machiavelli, Francesco Vettori mentions a confidential code that Machiavelli used to correspond with others (L 393, 398). Therefore, Machiavelli seems perfectly approving of hiding one's thoughts from unintended readers.

\footnotetext{
over the centuries. In other words, the esoteric method of reading is not only useful for interpretation of Machiavelli; it has also been used by other scholars for the interpretation of many other thinkers.

16. Niccolò Machiavelli, The Chief Works and Others-Volume I, trans. Allan Gilbert (Durham, NC: Duke University Press, 1965), 116, 118.
} 
To a certain Luccan secretary whose letter condemning the punishment of Paolo Vitelli had been intercepted, Machiavelli writes that among "the many considerations that show what a man is, none is more important than seeing [...] how carefully he invents [fingere = fakes, feigns] what he wants to convince others of.' He calls someone who cannot fake credible stories someone of no prudence (di nessuna prudentia). Machiavelli criticizes his addressee for not knowing how to justify the harsh treatment of Vitelli with every means possible (L 22). ${ }^{17}$ Faking stories to persuade others is therefore clearly advocated by Machiavelli. Another correspondent of Machiavelli, Roberto Acciaiuoli, mentions the "requirement of silence, for which you cannot be praised sufficiently" as being the mark of a good secretary (L 25). Moreover, in Florentine Histories, Machiavelli reports the "obscurity" of the letters written by the commander of the pope's armies, Giovanni Vitelleschi. According to him, Vitelleschi's letters were written in "unusual characters and the sense was so complicated that one could not draw any particular meaning from them" (FH V.27.218). Machiavelli's ordinary writings are not of course in unusual characters, but Benedetto Croce's judgment that Machiavelli's writings are an enigma that may never be resolved brings Vitelleschi's writings to mind. ${ }^{18}$ The writings of both are so complicated that to draw any coherent meaning from them seems impossible.

Machiavelli was an advocate of a citizen militia, and during the short life of the Florentine Republic he was put in charge of its militia. He was responsible for recruitment and reorganization of Florence's military defenses. Although he never served in the army, his administrative abilities and experience with warfare were considerable. Through his extensive study of ancient Greek and Roman military histories and manuals, he was thoroughly familiar with siege warfare, weapons technology, logistics, troop formation, and other aspects of the army. Many of his writings on military questions include passages that bring esotericism to mind. For instance, in Discourses, he mentions Fabius's speech to his soldiers in which he refrained from giving them some information that demonstrated that victory was certain, since it was "dangerous to make [that information] manifest." Machiavelli believes that Fabius's action was wise,

\section{Ridolfi, 29.}

18. Benedetto Croce, "Una questione che forse non si chiuderà mai: La questione del Machiavelli," Quaderni della critica 5.14 (1949): 1-9. 
and he thinks "it deserves to be imitated" (D 3.33.287). In the same book, he explains that a commander should not put his faith in the enemy's evident blunders, since "fraud will always be underneath." However, Machiavelli's rule is itself an evident blunder since he then proceeds to discuss an evident error committed by the Romans that did not have a fraudulent intention (D 3.48.308) ${ }^{19}$ Such evident mistakes are of course abundant in Machiavelli's own writings, and one might reasonably suspect there is some intention underneath them. The same theme is discussed in Art of War, in which Fabrizio counsels his interlocutors to be cautious about trusting any enemy's actions that are unreasonable because a deception will be hidden within them (AW 5.113). Fabrizio also believes that the besiegers should not be deceived by an enemy who always follows the same procedure or performs an action repeatedly since there might a deception beneath (AW 7.96ff). The same character teaches that the besieged communicate through deciphered letters and that the best policy is the one hidden from the enemy until it is accomplished (AW 7.123ff, 158).

One might object that these passages clearly refer to warfare and not to the writing of books. However, one should not minimize the importance of these references, because in Machiavelli's works, practically everything, from love to religion and politics, is a kind of war. The language of love in Machiavelli's comedies is the language of war, battles, and armies, and religion is called the art of peace. He writes of armed and unarmed prophets, counts Moses and David as being among his best princes, and in The Prince, the whole of politics is reduced to the art of war (M 181, 253; C 299; D 1.11.34, 1.19.52, 1.9.3; P 6.22, 14.58). ${ }^{20}$ Why should writing be any different for Machiavelli? Is it possible that for him, warfare is in fact an allegory for intellectual debate? As we shall see later, Machiavelli is aware of the importance and utility of metaphors and allegories in conveying secret meanings to the reader.

Readers of The Prince and especially of Discourses know that Machiavelli thought carefully about conspiracies. In fact, one of the distinguishing elements of Machiavelli's thought is his preoccupation, or one might say, obsession with conspiracy. Chapter 6 of the third book of Discourses - the longest chapter in any of Machiavelli's books, practically an independent short treatise-is the one dedicated to conspiracy. Moreover, Machiavelli's comedies are all conspiracies 
against established authorities: Mandragola and Clizia against the marital and religious authorities and Andria against paternal authority. Esotericism is also a kind of conspiracy between the author and his select readers who share in the esoteric meaning of the text-the meaning that might be incompatible with the established order of society. Therefore it is not unreasonable to study this topic to understand Machiavelli's art of writing.

With regard to the question of conspiracy, a discussion in chapter 8 of The Prince is significant. There, Machiavelli mentions the example of Oliverotto da Fermo, who acquired the principate through crime. Oliverotto gave a banquet to which he invited his maternal uncle and the first citizens of Fermo. During the conversation, he "opened certain grave discussions." The subject of these grave discussions was "the greatness of Pope Alexander and of Cesare Borgia" and their undertakings. Oliverotto then asked the participants to withdraw into another room, since these things should be spoken of in "a more secret place," where he kills all of them. The reader becomes naturally curious about the content of the discussion that made the participants fall for Oliverotto's trap. What should not have been overheard by unfriendly ears? The reader also remembers that the subjects of the previous chapter in the book (7) were in fact Pope Alexander, Cesare Borgia, and their undertakings. Moreover, the details of Oliverotto's story are actually fabricated by Machiavelli, supposedly to make an important point (P 8.36-37). ${ }^{21}$ In Florentine Histories, Machiavelli also describes the conspiracy of Stefano Porcari. The latter wanted to "take his fatherland from the hands of prelates," rescue it from their "evil customs," and "restore its ancient way of life." Machiavelli, in a work dedicated to the pope, judges that Porcari's intention "could be praised by anyone." The only fault he finds in Porcari's enterprise is that he was unable to conduct himself "in a mode cautious enough not to reveal himself by his words, his habits, and his mode of living." Machiavelli's description of Porcari's personality is brief, but we know that like Machiavelli, Porcari was an admirer of Livy; he befriended Leonardo Bruni and other humanists of the time, and some extant humanist literary works are dedicated to his conspiracy. Machiavelli's laconic allusion to Porcari's noble "learning" is probably a passing reference to his humanistic background. Moreover, Machiavelli mentions that Porcari was moved to action by a canzone of Petrarch, the same poet whose verses are quoted at the end 
of The Prince as an exhortation to free Italy from the Barbarians. One might suspect that Machiavelli, famous for his condemnation of the prelates, would not be as imprudent as Porcari and would not conspicuously "reveal himself" in his writings and words (FH 6.29.264). ${ }^{22}$

The evidence mentioned thus far only prepares the reader to acknowledge the possibility of esotericism in Machiavelli's writings. It is necessary to go beyond the general suspicious attitude and introduce further evidence for the existence of esotericism in Machiavelli's writings.

\section{Esoteric forms in Machiavelli's writings}

Apart from The Prince and Discourses, Machiavelli is the author of works that do not take the conventional form of a treatise: for instance, his so-called literary writings. We might encounter less opposition if we propose an esoteric reading of Machiavelli's literary writings, since the structure of these writings lends itself to esoteric reading. Attention to the hidden intentions behind literary works is a common practice. Even though some commentators have denied the existence of any lesson or teaching behind his comedies, ${ }^{23}$ Machiavelli himself explains that a comic writer must compose his comedy so that it excites laughter and makes the audience "taste afterwards the useful lesson that lay underneath" (O 929). ${ }^{24}$ Moreover, in Discourses, in order to demonstrate the arguments of those who say that distancing the enemy from his home is advantageous in defeating him, Machiavelli mentions a "poetic fable" and uncovers its deep meaning (D 2.12.152). Of course, speaking and giving lessons through metaphor, allegory, fable, poetry, and literature are not uncommon. For instance, Dante, one of Machiavelli's favourite writers, invites his readers to discover the "meaning that

22. Anthony F. D'Elia, “Stefano Porcari's Conspiracy against Pope Nicholas V in 1453 and Republican Culture in Papal Rome," Journal of the History of Ideas 68.2 (2007): 207-31; Arjo Vanderjagt, "Civic Humanism in Practice: The Case of Stefano Porcari and the Christian Tradition," in Antiquity Renewed: Late Classical and Early Modern Themes, ed. Zweder von Martels and Victor M. Schmidt (Leuven: Peeters, 2003), 63-78.

23. Niccolò Machiavelli, The Literary Works of Machiavelli: With Selections from the Private Correspondence, trans. J. R. Hale (Oxford: Oxford University Press, 1961), xii.

24. Machiavelli, The Literary Works, 188. 
is hidden beneath the veil" of his verses. ${ }^{25}$ However, literary devices are also classic instruments of esoteric writing by which one can convey unorthodox views to careful readers while avoiding persecution or public censure. As Jorge Luis Borges reminds us, "censorship is the mother of metaphor." ${ }^{26}$

As esoteric devices are used primarily for conveying radical and dissident teachings, one should consider whether the lesson conveyed through these literary devices in Machiavelli's works is unorthodox and iconoclastic. The answer seems positive. For instance, in the prologue to Mandragola, Machiavelli gives the gist of the story by saying that Callimaco loved Lucrezia and "tricked" (ingannata) her. Enigmatically, he hopes that the audience "might be tricked" as Lucrezia was. In the song after the third act of the play, "the trick [inganno]" is called the "remedy" that shows "the straight path to wandering souls." Machiavelli's Mandragola, like other comedies, makes the audience identify with the characters imitated in the play. However, what is to be imitated in Machiavelli's case is nothing conventional. Machiavelli uses Mandragola to teach the young how un giovane seduces una giovane away from her husband and consequently from her old-fashioned moral scruples. In traditional comedies, deviant figures are unmasked and sometimes punished; in the end, the traditional order is restored and morality is vindicated. However, Machiavelli's comedies are not traditional. There is no poetic justice; rather, the wicked prosper. Machiavelli does everything to make alluring what would ordinarily be censured as sinful and immoral, and he encourages the cooperation of his audience. Commentators have observed that Mandragola is in fact no satire, "for it includes no dramatic assertion of an alternative standard which would invite criticism of the mode of life depicted."27 The characters who should be considered villains from the point of view of religion and tradition are instead designed to arouse the sympathy of the audience. Considering the questionable character of the remedy discussed in Mandragola, it should come as no surprise that Machiavelli would convey his teaching esoterically: he teaches implicitly through a light-hearted comedy-and speaks through the

25. Dante, The Divine Comedy: Volume 1-Inferno, trans. Mark Musa (New York: Penguin Books, 1984), $9.60-63$.

26. George Steiner, "Language under Surveillance: The Writer and the State," New York Times Book Review (12 January 1986), 36.

27. Robert B. Heilman, The Ghost on the Ramparts and Other Essays in the Humanities (Athens: University of Georgia Press, 2008), 160; Flaumenhaft, 61. 
mouths of its characters-what he could not say explicitly in a treatise on the subject in his own name. One must bear in mind that the literary genre of comedy in ancient as well as modern times allowed for a high degree of social and religious ridicule that would not have been acceptable in any other form..$^{28}$

In the same vein, the prologue to Clizia puts forward one of Machiavelli's key ideas: the trans-historical character of human nature that produces the same effects in different times. The story of an amorous rivalry between son and father in classical Athens, according to Machiavelli, occurred "once again, here in Florence." However, Machiavelli, "in order to avoid carico [...] has changed the real names into fictitious ones." David Sices translates carico as "legal charges" (C 281). Regardless of how this word is translated ("disapproval" or "charge" would be more accurate), it is certain that Machiavelli does not consider it prudent to openly disclose his intention, for it goes without saying that he means that something akin to his comedy has happened in Florence, not that his story has literally happened in that city. In other words, the story depicted in Clizia is an allegory of something else that occurred in Machiavelli's time. To find the real non-allegorical example is to uncover Machiavelli's esoteric intention. His esoteric technique consists of using a literary form to convey his message.

The Ass (L'Asino), Machiavelli's other literary work, is also a candidate for esoteric reading: as an allegorical writing, it shares that genre's intellectual puzzles. Human concepts like fame and justice are given animal forms, thereby encouraging the reader's interpretative efforts. Confronting The Ass, the reader must go beyond the literal surface to uncover the author's intention and meaning. But why did Machiavelli need to resort to allegorical poetry in order to communicate his intention? Why did he not write a philosophical treatise on his subject? He could have pursued literature for different reasons, including the one he gives in Mandragola's prologue: namely, that he has been deprived of other means of showing his worth. In other words, the choice of poetic form might be only a matter of taste. However, if we follow Paul A. Rahe's reading, The Ass's message demands esoteric writing. According to Rahe, in this poem Machiavelli is following his revered authority, Lucretius, in criticizing the very

28. Martin Revermann, "Divinity and Religious Practice," in The Cambridge Companion to Greek Comedy, ed. Martin Revermann (Cambridge: Cambridge University Press, 2014), 275-87. 
possibility of divine providence. ${ }^{29}$ It would therefore make sense to hide such an intention by writing allegorically. Rahe's interpretation is not the only one that justifies an esoteric reading of The Ass. The different animals presented in the work clearly represent the emblems of distinguished families of Florence. The editor of the text in 1549 even censored some lines that he must have thought to be too obvious (O 971). One might also mention the lost play of Machiavelli, The Masks (Le Maschere). According to Giuliano de' Ricci, Machiavelli's heir and the editor of his manuscripts, in this imitation of Aristophanes's comedies, Machiavelli attacked "under feigned names, many citizens who were still living in the year 1504." Unfortunately, de' Ricci decided not to copy the manuscript. It is noteworthy that while discussing Le Maschere's content, de' Ricci also mentions that Machiavelli reduced "all things to natural or fortuitous causes," which can hardly be considered an orthodox position. ${ }^{30}$

Apart from strictly literary writings, Art of War is also a dialogue that uses literary devices. In other words, this work is not a treatise, and the author mostly does not speak directly to the reader. In the beginning of the dialogue, the interlocutors move to a "secret and shady part of" the garden to have a discussion. Presumably the host, Cosimo Rucellai, does not think that such a discussion should be held in public. ${ }^{31}$ This allusion to the secret nature of the dialogue becomes more meaningful when we know more about the setting of the dialogue, i.e., the Orti Oricellari garden. A year after the publication of Art of War, three of the men mentioned in the dialogue (Zanobi Buondelmonti, Batista della Palla, and Luigi Alamanni) had to leave Florence because of their involvement in a republican conspiracy against the rule of the Medici family. The setting of the discussion belonged to the Rucellai family and had been a major

29. Paul Rahe, "In the Shadow of Lucretius: The Epicurean Foundations of Machiavelli's Political Thought," History of Political Thought 28.1 (2007): 43.

30. William J. Landon, Politics, Patriotism, and Language: Niccolò Machiavelli's "secular Patria" and the Creation of an Italian National Identity (New York: Peter Lang, 2005), 55. Compare with Savonarola: "Tutte le cose che sentono, questi filosofi e astrologi le vogliono risolvere in cause naturali, o attribuirle al cielo più presto che a Dio" (cited in Strauss, Thoughts on Machiavelli, 335n82). For Machiavelli's view of Christianity, see his writings on the Christian persecution of paganism as well as the allusion to the eternity of the world in D 2.5.138-39.

31. AW 1.12. Compare with the story of Oliverotto da Fermo, who "opened certain grave discussions" and asked the participants to withdraw into another room and discuss things in "a more secret place." P 8. 36-37. 
centre of humanist thought in Florence. After the restoration of the Medici rule in 1512, Orti Oricellari also became a place for the gathering of politicallyminded republicans. Machiavelli participated in these gatherings, and he might have shared his other writings with the participants, including The Prince and Discourses, with its famous and unique chapter on conspiracies. By choosing such a venue for his dialogue, Machiavelli connects his work with a politically suspect place. Maurizio Viroli goes so far as to suggest that Machiavelli himself had been involved in the ill-fated conspiracy of his friends. ${ }^{32}$ One of the same interlocutors also appears in Discourses among those who deserve to be princes. Machiavelli's use of dialogue as a literary device is not lacking in significance either. In the beginning of the first book, Machiavelli says that he was himself present in the imaginary dialogue, but we never hear him speak (AW 1.8). He withdraws and removes himself from the discussion and the ideas presented therein. In fact, contrary to what most commentators assume, it would be unreasonable to call Fabrizio simply Machiavelli's spokesman, unless we also attribute Hamlet's words to Shakespeare. Machiavelli speaks in his own voice only in the preface and in the first part of the first book. Moreover, Machiavelli is himself present in the dialogue, so why would he be represented by another character? His thoughts and intentions can only be discovered by considering the whole dialogue, the discussions, and the actions of different characters. In other words, the literary character of the book itself forces the reader to go beyond the surface of the literal words and begin an esoteric interpretation of the dialogue. Attention to the dramatic structure of dialogues might look unorthodox to the commentators who are accustomed to considering it a trivial and secondary stylistic characteristic. But, attention to the dramatic form in fact goes back at least to Neoplatonists and their commentaries on Platonic dialogues. The dialogic form of writing has been a favourite technique of esoteric writers for centuries; it can be compared with the Machiavellian idea of attributing one's own opinions to a third person. ${ }^{33}$ It is reasonable to think

32. Viroli, Niccolo's Smile, 220; Gilbert Felix, "Bernardo Rucellai and the Orti Oricellari: A Study on the Origin of Modern Political Thought," Journal of the Warburg and Courtauld Institutes 12 (1949): 101-31.

33. For instance, Augustine argues that Cicero was an atheist but used the characters in his dialogues to voice his opinions, thus concealing his own views. Augustine, The City of God, trans. Marcus Dods (New York: Modern Library, 1950), 152-53. When Machiavelli speaks in his own name he is a very cautious and ambiguous writer: $\mathrm{cf}$. the critique of Christianity which is put in the mouth of Fabrizio (AW 2.305) with the esoteric version of the same critique in D 2.2.131-32. 
that Machiavelli's recourse to the dialogic form is not only a stylistic decision but actually essential to the meaning of the whole work.

\section{Machiavelli's esoteric confessions}

The evidence heretofore provided might fall short of perfect clarity and therefore prove unpersuasive to some readers. One must therefore think about what kind of evidence would be more persuasive. Of course, the most convincing way of knowing and proving the existence of esotericism in Machiavelli's writing would be if Machiavelli himself told us. In fact, Strauss also proposes the search for "explicit evidence" as one of the first necessary steps to any esoteric interpretation. ${ }^{34}$ If one looks through Machiavelli's writings, several passages can be considered to be instances where Machiavelli speaks about his own esotericism. One of these examples is a letter addressed to Guicciardini, which includes three significant passages related to esotericism. First, Machiavelli mentions that he has always tried to help his native city, "if not with deeds, then with words; if not with words, then with signs [cenni]." Second, he boasts of his own "hypocrisy [ippocrito]", which makes him immune to the hypocrisy of the friars. The third passage is more revealing: Machiavelli mentions his immunity against "the lies of these citizens of Carpi," because he considers himself "a doctor of this art." This is followed by the famous statement: "for some time now I have never said what I believe or never believed what I said; and if indeed I do sometimes tell the truth, I hide it behind so many lies that it is hard to find." It is significant that most commentators who reject an esoteric interpretation of Machiavelli do not quote these lines. The passage is by no means self-explanatory and might not prove Machiavelli's esotericism beyond any reasonable doubt. However, one cannot deny that it is very suggestive (L 337). ${ }^{35}$ One might believe that Machiavelli is only making some provocative remark about himself to his friend. Nevertheless, it is undeniable that he seems particularly proud of his secretive nature. Therefore, it would not be surprising if he also applies this secrecy to his public writings that discuss religious questions. In fact, the same series of letters between Guicciardini and Machiavelli contains some rather

34. Leo Strauss, Persecution and the Art of Writing (Chicago: University of Chicago Press, 1952), 32.

35. See also Niccolò Capponi, "Review of Art of War, by Niccolò Machiavelli, Translated by Christopher Lynch," Renaissance Quarterly 57.3 (2004): 981. 
interesting remarks about Machiavelli's impious character (see, e.g., L 335, 336, 336, 342).

Guicciardini appears to be Machiavelli's most trusted correspondent: Machiavelli is more forthcoming with him than he is with others. In another letter addressed to Guicciardini, Machiavelli first surveys the political circumstances of the day and then writes that if he "were talking to a man who was ignorant of secrecy or who was unaware of the world," he would explain his views in more detail. ${ }^{36}$ Again, in a letter to the same correspondent, mentioning his work on Florentine Histories, Machiavelli writes that he would like to have him by his side since he is "about to come to certain details" and wants to know whether he is "too offensive" in his "exaggeration of the facts." $\mathrm{He}$ is trying to do his "best to arrange it [ingegnerommi] so that [...] no one will have anything to complain about" (L 351). The case of Florentine Histories is particularly important for the discussion of esotericism: Machiavelli was commissioned to write the book by Giulio de' Medici, a member of the ruling family in Florence who had become pope by the time the book was presented to him. Moreover, an important part of the work covers the history of Florence from the year 1434 until the death of Lorenzo the Magnificent, i.e., from the year in which the Medici family acquired supreme power until the death of the last effective member of the family preceding its fall in 1494 and the restoration of the republican regime. The book, then, is particularly apt for esoteric writing in order to avoid persecution and the displeasure of the Medici. In fact, Machiavelli writes about this problem in his book. In the dedicatory

36. L 387. Machiavelli ends his letter with an enigmatic Latin phrase: "Liberate diuturna cura Italiam, extirpate has immanes belluas, quae hominis, preter faciem et vocem, nichil haben" (Free Italy from long-lasting anxiety; eradicate those savage brutes, which have nothing human about them save their faces and voices). The phrase is an allusion to Hannibal, who before drinking from his poison cup said: "Liberemus diuturna cura populum Romanum quando mortem senis exspectare longum censent" (Let us relieve the Romans from the anxiety they have so long experienced, since they think it tries their patience too much to wait for an old man's death). The meaning of Machiavelli's phrase is far from clear. He exhorts his friend to the liberation of Italy by alluding to the dying words of the enemy of ancient Italy. From whom must "Italy" be liberated? The new Hannibal, or rather the new Romans? Machiavelli seems worried about Pope Clement VII losing his immediate opportunities. See in light of the title of chapter 26 in The Prince, and also Robert Fredona, "Liberate Diuturna Cura Italiam: Hannibal in the Thought of Niccolò Machiavelli," in Florence and Beyond: Culture, Society and Politics in Renaissance Italy-Essays in Honour of John M. Najemy, ed. David S. Peterson and Daniel E. Bornstein (Toronto: Centre for Reformation and Renaissance Studies, 2008), 431-32. 
letter to the pope, he writes that he has tried to "satisfy everyone" in his history "while not straining the truth." But then he adds that "perhaps" he did not satisfy everyone because it is "impossible without offending many to describe things in their times" (FH Ded.5). Machiavelli is in a difficult predicament, an impossible position that has two contradictory requirements: telling the truth or satisfying his audience, particularly the Medici family and their supporters. In this regard, Machiavelli's confession about Florentine Histories-which was reported by Donato Giannotti, one of his acquaintances and sometimes referred to as one of his intellectual heirs-is significant. Machiavelli has reportedly told him that in his book he could not write as he would write if he were free from "all hesitations [rispetti]." He then gives the example of Cosimo de' Medici's rise to power and says that "whoever wants to learn this also may note very well what I will make his adversaries say." ${ }^{37}$ Contrary to what one might think, this confession is not only about Cosimo-he is simply one example mentioned by Machiavelli. ${ }^{38}$ Because of Giannotti's report, one might suspect that Machiavelli has strained the truth in many parts of his history to satisfy some of his readers. At the very least, Machiavelli shows himself to be fully aware of the contradictory nature of teaching the truth and pleasing everyone. Meanwhile, we should remember that in his letter to Guicciardini, Machiavelli mentions his "exaggeration of the facts" in the book. Moreover, while concluding his remarks on Cosimo's career in Florentine Histories, he excuses himself by saying he was "compelled of necessity to praise him in an extraordinary mode" (FH VII.6.284, emphasis added). One might suspect that many other invented speeches and facts in Florentine Histories might also be examples of Machiavelli's esotericism, especially those speeches that discuss surprisingly "Machiavellian" ideas. Examples are the speech of the Milanese ambassadors and the famous wool worker's speech, which Strauss aptly calls the "most Machiavellian passage" of the whole book. ${ }^{39}$

\section{Mansfield, Machiavelli's Virtue, 134.}

38. See Maurizio Viroli, From Politics to Reason of State: The Acquisition and Transformation of the Language of Politics 1250-1600 (Cambridge: Cambridge University Press, 1992), 168-69.

39. Cf. FH 6.20.251-52 with P 12.52-53 and D 2.13.155. For the wool worker's speech: FH 3.13.122-23. Interestingly, the speech also contains surprising passages about God's justice. See also Francesco Sforza's reply and his understanding of God's justice in FH 6.21.253 and Strauss, Thoughts on Machiavelli, $127-31$. 
A similar case of Machiavelli's own allusion to his silence about crucial topics appears in his short writing on the life of Castruccio Castracani. In the short prologue to the work, he explains that those excellent men who have done very great things have been of humble and obscure origin. These men, to hide their dishonourable origins, have pretended to be sons of Jove or some other "God [Dio]" (capitalized in the original). Machiavelli does not name those he has in mind and justifies his silence by saying that these men "are known to everybody"; therefore, it would be fastidious and "little acceptable to readers [poco accetta a chi leggessi]" to repeat their stories (O 615). Castruccio is, according to Machiavelli, among those of humble and obscure origin. Now, what Machiavelli says in the prologue seems unnecessary, because in fact the historical Castruccio was a legitimate child and only orphaned when he was nineteen years old. Machiavelli's fictional biography makes us think of Romulus, Remus, and Moses instead, hence his allusion to other examples of such excellent men. ${ }^{40}$ However, Romulus and Remus are not entirely fitting examples. According to Livy, the twins were found and suckled by a she-wolf, while according to Machiavelli, Castruccio was found by the sister of a priest. ${ }^{41}$ Moses seems a more promising case since he was discovered by the Pharaoh's daughter. Moses was not of course the son of God, but God "spake unto Moses face to face, as a man speaketh unto his friend"-at least, this is what Moses pretends in his own book. Moreover, Moses is sometimes compared to the "second Moses," i.e., Jesus, the Son of God..$^{42}$ In light of the resemblance between Moses, Jesus, and Castruccio, one is tempted to look with more suspicion at Machiavelli's allusion to the unwelcoming readers. Why would he refrain from mentioning other examples of such excellent men? What is it that he believes

40. Theodore A. Sumberg, “Machiavelli’s Castruccio Castracani,” Interpretation 16 (1988): 285. Some of the other differences between Machiavelli's representation of Castruccio and historical facts are mentioned in Pasquale Villari, The Life and Times of Niccolò Machiavelli (New York: Scribner, 1891), 2.302-08.

41. Livy, The Early History of Rome: Books 1-5, trans. Aubrey de Sélincourt (London: Penguin Books, 1960), 1.4. Livy also mentions another tradition in which the twins were born to and nursed by a common whore.

42. Exodus 2:5, 33:11; Acts 7:37, 39-43, 51-53; Revelation 11:3ff. Compare with the remark in D 1.11.35 that Lycurgus, Solon, and "many other" lawgivers had recourse to God in order to persuade the citizens with the reference to "Moses, Lycurgus, Solon, and other founders" in D 1.9.30. See also D 2.8.145: "Joshua the robber son of Nun." The Latin word for Joshua is also used for Jesus. For the significance of "robber," see Mansfield, Machiavelli's New Modes and Orders, 76. 
his readers would not accept? It is not unreasonable to believe that Machiavelli refrained from mentioning other examples because of the religious scruples of his readers or fear of persecution. One might add that most of the philosophers whose aphoristic wit Machiavelli attributes to his excellent prince Castruccio are not the canonical fathers of ancient philosophy, but rather "atheist philosopherrascals such as Bion, Diogenes, and Aristippus." ${ }^{33}$ The pseudo-historical style of the writing is the perfect device for Machiavelli to distance himself from his role model and the curious aspects of his life. As we shall see, Machiavelli considers historical works a common instrument for conveying one's own teaching.

Still, one should bear in mind that regardless of the value of these passages for proving the existence of esotericism in Machiavelli's works, it is in fact quite remarkable to even encounter such references by Machiavelli to his own esotericism. Although references to esotericism in the history of philosophy are much more numerous than one might think, references to one's own esotericism are extremely rare. ${ }^{44}$ In this respect, Pocock's allusion to falasifa and their esoteric confessions is significant. Pocock does not explain what he thinks Machiavelli should have said to make an esoteric reading of his works perfectly uncontroversial, but it should be mentioned that neither Alfarabi, Avicenna, nor Averroes admits to his own esotericism; they only speak about Aristotle's, Socrates's, or Plato's esotericism. ${ }^{45}$ Moreover, it is not actually decisive whether Machiavelli mentions his own esotericism or not; as we shall see, those writers whom Machiavelli himself considers esoteric do not mention their own esotericism either. ${ }^{46}$

43. Jeffrey T. Schnapp, "Machiavellian Foundlings: Castruccio Castracani and the Aphorism," Renaissance Quarterly 45.4 (1992): 666. Compare with L 328.

44. For instance, Plato's references to his own esotericism all come from his letters, the authenticity of which has been the subject of dispute: Plato, Seventh Letter 341d-e, 344c-e. Even in these passages, it is difficult to conclude that Plato is speaking of his own writings.

45. Alfarabi, "The Harmonization of the Two Opinions of the Two Sages: Plato the Divine and Aristotle," in The Political Writings: "Selected Aphorisms" and Other Texts, trans. Charles Butterworth (Ithaca, NY: Cornell University Press, 2001), 131; Alfarabi, “Le Sommaire Du Livre Des 'Lois' de Platon,” ed. ThérèseAnne Druart, Bulletin D'études Orientales 50 (1998): 125; Avicenna, “On the Proof of Prophecies," in Medieval Political Philosophy: A Sourcebook, ed. Ralph Lerner and Muhsin Mahdi (New York: Free Press Glencoe, 1963), 116; Averroes, Averroes on Plato's "Republic," trans. Ralph Lerner (Ithaca, NY: Cornell University Press, 1974), 24.

46. One should mention that whether Machiavelli is correct in attributing esotericism to some specific writers is not important for our case. Machiavelli could be wrong, but by reporting on the esotericism 


\section{Machiavelli's esoteric readings}

If for many scholars the falasifa's references to the esotericism of other writers are sufficient for justifying the esoteric reading of their own works, Machiavelli's references to the esotericism of others should be of particular interest. Fortunately, such references are not scarce. The most recurring example of Machiavelli's allusions to the esotericism of other writers is in the case of Titus Livy. For instance, writing to Francesco Vettori, Machiavelli justifies his criticism of the neutrality policy by mentioning Livy who also subscribed to this opinion "when putting [...] words in the mouth of Titus Flaminius" (L 304). For Machiavelli, in many instances, Livy speaks through his characters: he puts his own thoughts "in the mouth" of his characters such as Valerius Corvinus, Publius Decius, and Camillius. Machiavelli even goes so far as to attribute a speech made by Gaius Sulpicious to Livy himself (D 3.33.286, 3.38.296, $3.40 .299,2.23 .181-82,3.10 .243)$. The most significant example of Machiavelli attributing a Livian character's speech to Livy is when he quotes the speech of Vettius Messius, the Volsci commander. In his complete speech as it is recorded in Livy's History, Messius says, "Do you believe that some god will protect you and carry you away from here?" However, in his quotation, Machiavelli omits this denial of the possibility of divine help. Immediately following his quotation of the speech, Machiavelli quotes another part of the same speech, but this time he attributes it to Livy, not Messius. In other words, Machiavelli attributes the speech of a Livian character that contains unconventional ideas about gods to Livy. It seems that according to Machiavelli, this speech, including the omitted part, reflects Livy's own opinion about the divine and providence (D 3.12.249). ${ }^{47}$ As we have seen, Machiavelli often recommends attributing one's own opinions to a third person, and these passages remind us of that precept. ${ }^{48}$

\footnotetext{
of another, he shows himself to be aware of the technique and the practice of esotericism. Moreover, it is possible that he is simply showing his reader how to read his writings esoterically. In other words, the same techniques used by Machiavelli for discovering the esoteric teaching of other writers might serve as instructions for reading his works in a similar manner.

47. Strauss, Thoughts on Machiavelli, 120, 140.

48. To attribute one's own opinions to a third person is of course a common practice. For instance, Niccolo Serristori, one of Machiavelli's close friends, gives an account of a violent conversation he had with a certain Antonio Segni in which, for criticizing the pope, he "spoke in the third person [in tertia persona]," putting his words in the mouth of "others" (L 173).
} 
In this regard, it becomes necessary to study speeches attributed by Machiavelli to historical characters more attentively. Other controversial and "invented" speeches that are attributed to Castruccio Castracani, Francesco Sforza, and others could simply be means by which Machiavelli conveys his own thoughts to esoteric readers like himself.

Speeches are not the only part of Livy's history that Machiavelli attributes to Livy himself: for Machiavelli, even what a character of Livy does is Livy's doing. According to Machiavelli, Livy agrees with him that the most important war in Roman history was the one waged against the Latins, since Livy "makes" the fighting armies alike in his narrative (D 2.16.160). In other words, even though Machiavelli calls Livy a historian, he practically makes him a writer of fiction (D 3.31.281). For Machiavelli, Xenophon also teaches the necessity of fraud for acquiring force, since in his Cyropaedia he shows or rather "makes" Cyrus seize his enemy's kingdom through fraud and not through force (D 2.13.155). In view of the fact that Machiavelli also invents many historical facts and events in his writings, one might suspect that he is also, like Livy and Xenophon, conveying his esoteric teachings through these inventions. ${ }^{49}$

Elsewhere, Machiavelli reinforces his own judgment according to which money is not the sinew of war by referring to Livy, who has omitted money from his discourse on Alexander. He therefore seems to be teaching his reader to discover other writers' opinions by identifying what is not mentioned and by reading between the lines (D 2.10.149). Moreover, Livy and Xenophon are not the only examples of Machiavelli's esoteric reading. In The Prince, for supporting his precept according to which the new prince cannot avoid the vice of cruelty, Machiavelli cites Virgil. However, Virgil does not approve of this precept himself and puts it "in the mouth of Dido," a character of his epic poem, instead (P 17.66; see also D 1.21.55). Perhaps the most revealing reference to esotericism in The Prince is found in chapter 18, which examines the question of keeping faith. At first, Machiavelli concedes that being faithful is praiseworthy. Nevertheless, he introduces one of his famous reversals that often go against the conventional view: he believes that breaking faith might sometimes be useful to princes. A prince should be flexible and ready to engage in two kinds of fighting, one that is proper to man and one that is not. In other words, he must be both man and beast. Machiavelli then tells us that 
this teaching was also "covertly [copertamente]" taught by ancient writers, for instance, when they made Chiron the centaur the preceptor of Achilles and many other ancient princes (P 18.69). In other words, Chiron is a metaphor used by writers to convey their covert teaching to judicious readers. One is therefore inclined to seek out similar allegories and metaphors in Machiavelli's works that convey his own esoteric teachings. In this regard, it is notable that the frontispiece of the first edition of Mandragola is the picture of a centaur like Chiron-the metaphor of covert teaching according to Machiavelli. In fact, the front page of the play does not bear the author's name: the centaur stands in for the author himself, as if it is his personal emblem. ${ }^{50}$ One is therefore tempted to see what kind of covert teaching underpins Mandragola or, for that matter, the author's other writings and allegories.

There are references to the esotericism of other writers in Machiavelli's writings that are more general in character. For instance, Machiavelli narrates the story of King Agis of Sparta who, according to him, desired to reform Sparta by returning it to the laws of Lycurgus, i.e., by restoring the ancient virtuous orders of the past. Agis is not unlike Machiavelli, who also wants to restore the ancient virtues of the Romans in his own times. But Agis is killed by the defenders of the established order. Later, his successor Cleomenes experienced the same desire after reading "the records and writings" of Agis in which "his mind and intention" were seen (D 1.9.30). However, Plutarch's account, which is Machiavelli's source, does not mention any writing of Agis by which Cleomenes could have been moved to action: the story seems "carefully faked" by Machiavelli, who seems interested in the intentions contained in subversive writings (L 22). In the same vein, Machiavelli argues that the cruelties of the multitude are well known through histories because writers do not fear speaking ill of ordinary people, while "princes are always spoken of with a thousand fears and a thousand hesitations" (D 1.58.119). In Florentine Histories, he also mentions other historians who were "restrained" and could not tell the whole truth so as "not to offend" the memory of the past generations (FH Preface.7). Moreover, persecution is not the only cause of historians' untrue accounts. According to Machiavelli, the memories of the ancient things, including those of the time before the biblical five thousand years, are eliminated-because after the heavenly catastrophes and floods, if 
someone is saved and knows about them, he "conceals it and perverts it" so that only what he wishes to "write" about remains for future generations. The truth of ancient times is not understood because it is often "concealed" by the writers (D 2.5.140, 2.preface.123).

Above all, there is one general reference in the Machiavellian corpus to the esotericism of other writers that is certainly the most important of its kind: in Discourses, Machiavelli speaks about praiseworthy private and political men such as Scipio. Caesar, according to him, is not among the excellent men worthy of our praise. Nevertheless, he adds that if writers have praised Caesar, it is because the Roman Empire "did not permit writers to speak freely of him." Nevertheless, the same writers intimated their true opinion about Caesar by praising his enemies instead or by blaming his predecessor, Catiline. Machiavelli therefore explains two other techniques esoteric writers can use to criticize the ruling powers. He himself certainly praises paganism, the enemy of Christianity, and it seems he criticizes Judaism, the predecessor of Christianity (D 1.10.32, 2.2.131, 2.8.144-45).

One intrigued by Machiavelli's more unambiguous remarks on esotericism naturally looks at his works in a new light. Some of the passages of his works then seem more suggestive than before. For instance, at the end of chapter 18 of The Prince, Machiavelli makes a curious statement that has puzzled commentators: he mentions a contemporary prince "whom it is not well to name" who only preaches "peace and faith" but is enemy of both. The allusion is thought to be to Ferdinand the Catholic, of whom Machiavelli speaks in chapter 21 . Alvarez believes this could also be a reference to Jesus. ${ }^{51}$ Whoever this contemporary prince might be, it is significant that Machiavelli leaves it to the reader to discover his identity: one might ask whether there are any other instances in his writings for which the reader must fill in the blanks; or consider his remark about Fabius, who showed his disagreement with the Senate "by being silent and in many other modes" (D 3.47.307) or his teaching according to which one must persuade a people of something by concealing its negative aspects underneath (D 1.53.106). Machiavelli uses the strongest words to state that everyone should abstain from writing since nothing convicts the writer more easily than "what is written by [his] hand." He believes men "should consider the times and accommodate themselves to them" and should not act 
like the unwise advisor of Perseus, who was killed for "having spoken when he ought to be silent" (D 3.6.223-25, 3.8.238, 3.35.292).

Are these ambiguous passages also allusions to esotericism, or are they only passing remarks about subjects unrelated to the secretive art of writing? Considering other more straightforward testimonies, one would be wise to remain reasonably suspicious. In his satire on fashionable society, Machiavelli expresses a rule that the members of the society should never reveal their true state of mind and that the one who knows best how to fake or to lie merits most commendation (O 932). In light of the fact that Machiavelli seems aware of the esoteric art of faking one's mind, one would do him an injustice if one does not at least consider him for commendation.

\section{Conclusion}

The question of esotericism in Machiavelli's writings is vital to our analysis of his works because it confronts us with a crucial problem: how should we read his works? If there is in fact any esoteric doctrine hidden within Machiavelli's writings, it concerns any commentator interested in any aspect of his thought. If Machiavelli wrote in an esoteric manner and the commentator reads him nonesoterically, he or she is bound to misunderstand Machiavelli's writings and doctrine. In other words, the question of esotericism has decisive importance for the practice of scholarship. My article has documented Machiavelli's own references to esotericism. Proving the existence of esotericism in Machiavelli's, or for that matter in anybody's writings, is difficult. Esotericism is fundamentally a covert enterprise and therefore resistant to exposure. Consequently, some of the evidence provided for its existence might lack perfect clarity. Nevertheless, considering the evidence presented in this article, we are confronted with the simple fact of numbers. One or two instances that lack clarity might prove unpersuasive. We might by scrupulous analysis eliminate some of the proofs for inexplicitness or lack of context. But if we encounter more than fifty quotations that all make the same general point, even if individually they lack persuasive effect, together they can persuade the doubtful reader to at least consider the possibility of esotericism in Machiavelli's works. There are of course no certainties when speaking about a secretive activity. The issue is whether the evidence for the existence of esotericism in the Machiavellian corpus is sufficiently strong to be taken into account by commentators. I believe I have 
provided sufficient evidence to make esotericism in Machiavelli's writings more than a possibility.

Strauss once noted that by taking into account the existence of esotericism as an undeniable fact, any reasonable "historian will reconcile himself to the fact that there is a difference between winning an argument, or proving to practically everyone that he is right, and understanding the thought of the great writers of the past." 52 Nietzsche also used to mock those who "ultimately prefer even a handful of 'certainty' to a whole carload of beautiful possibilities," and choose "even a certain nothing to an uncertain something." ${ }^{33}$ However, in a sense, the whole enterprise of modern scholarship is built on what Nietzsche despised. Scholars are bound by what we can certainly prove. We might therefore seem to be compelled by our profession to become "puritanical fanatics of conscience" instead of "stronger and livelier thinkers who are still eager for life." ${ }^{44}$ The objective of this study was to avoid this tragic decision and assist the reader in reasonably choosing to read Machiavelli esoterically without sacrificing scholarly criteria.

Of course, it is one thing to prove the existence of esoteric doctrine and entirely another to show what that esoteric doctrine is. Herein lies a major problem: proving its existence is not even half the battle. There is a real possibility that esotericism can be abused by commentators and open the door to all kinds of fantastic interpretations. By admitting the possibility of esotericism, overinterpretation and imaginary readings become real dangers, for how one can ever know that one has arrived at the author's true esoteric teaching? One may respond that while in esoteric interpretation, overinterpretation is the danger, denying the possibility of esotericism also encourages underinterpretation. Moreover, the possibility of mistakes is not limited to esoteric interpretation. Other approaches to reading texts do not have a better track record and have also produced uncertainty and disagreement. Meanwhile, the necessary step toward a creative dialogue with the esoteric commentators of Machiavelli is to accept the existence of esotericism as a historical fact and then proceed to criticize an interpretation of specific passages and texts. Many interpretations

52. Strauss, Persecution and the Art of Writing, 30.

53. Friedrich Nietzsche, Beyond Good and Evil: Prelude to a Philosophy of the Future, trans. Walter Kaufmann (New York, NY: Vintage Books, 1989), a.10.

54. Nietzsche, a.10. 
are open to obvious objections, and under close scrutiny some might prove untenable. Therefore, they should be discussed by other commentators. My objective was to make possible such a discussion. I contend that a commentator can reasonably subscribe to esoteric methods of interpretation without agreeing with any specific reading of Machiavelli. What I did not propose was any particular esoteric teaching of Machiavelli or any specific esoteric reading of his works. But in the end, if authors and important philosophers such as Francis Bacon, Baruch Spinoza, Jean-Jacques Rousseau, and Denis Diderot have read Machiavelli as an esoteric thinker who writes one thing but means another, it should not be unreasonable to give at least a hearing to those who agree with them..$^{55}$

55. "[a]lmost in plain terms" (emphasis added) in Francis Bacon, The Major Works, ed. Brian Vickers (Oxford: Oxford University Press, 1996), 363. See also Benedict Spinoza, The Chief Works of Benedict Spinoza, trans. H. M. Elwes (New York: Dover Publications, 1951), 315; Jean-Jacques Rousseau, Euvres Complètes IV (Paris: Gallimard, 1964), 409, 1481n4; Denis Diderot, Euvres Complètes de Diderot-Tome VII, ed. John Lough and Jacques Proust (Paris: Hermann, 1976), 3-7; Alberico Gentili, De Legationibus Libri Tres, trans. Gordon J. Laing (New York: Oxford University Press, 1924), 2.156; Rahe, Against Throne and Altar, $6 \mathrm{n} 8$. 
